\section{Exploring the benefits of service productisation: support for business processes}

Service
productisation
in business
processes

Industrial Engineering and Management, Faculty of Technology, University of Oulu, Oulu, Finland

Received 28 January 2021 Revised 8 July 2021 Accepted 3 September 2021

\begin{abstract}
Purpose - The study aims to explore the benefits of service productisation to provide further understanding on the productisation concept as support for business processes and service management. The concept has been deficiently discussed regardless of the potential significance to the whole formed by service products, business processes, information technology (IT), people and data.

Design/methodology/approach - In the study, the exploratory empirical evidence is presented from 16 cases, 4 of which are from companies that are globally well-known.

Findings - The key findings of the paper include an overview of the benefits of service productisation and the relation to service offering, service processes and related resources. The concept links to the management of the whole formed by service products, business processes, IT, people and data. The noted benefits seem to be applicable to productisation of different service types, whilst some service characteristics may affect the specific emphasis.
\end{abstract}

Research limitations/implications - The limitations involve using secondary data, which, however, makes the cases less biased regarding the aims. Primary data are required to gain further insights into the phenomena and the identified benefits.

Practical implications - The findings provide support for issues that are commonly discussed by practitioners on a concept that is less studied by the scientific literature. Practitioners can work towards organisational efficiency and effectiveness by understanding the benefits of productisation. Understanding service productisation can support the effective management of business processes and work towards prosperity in the service business.

Originality/value - The study is the first one to analyse the benefits of service productisation by exploring the issue through multiple cases and attempting to identify aspects for further attention by the academic community.

Keywords Service productisation, Productization, Service management, Business processes, Service product, Productization of services, Benefits of productisation

Paper type Research paper

\section{Introduction}

Service productisation is discussed as a formalisation type of service innovation by the literature Hemple (2015), Valtakoski and Järvi (2016) and as a set of activities to define and combine suitable elements into a product-like object that is repeatable and comprehendible (Harkonen et al., 2015). The innovation, in this context, relates to the determination and optimal organisation of service content to meet customer needs. The productisation concept is presented to contribute towards competitiveness and efficiency in services whilst facilitating their understanding (Valminen and Toivonen, 2012). However, regardless of the increasing number of publications referring to service productisation, certain ambiguity has

(C) Janne Harkonen. Published by Emerald Publishing Limited. This article is published under the Creative Commons Attribution (CC BY 4.0) licence. Anyone may reproduce, distribute, translate and create derivative works of this article (for both commercial and non-commercial purposes), subject to full attribution to the original publication and authors. The full terms of this licence may be seen at http:// creativecommons.org/licences/by/4.0/legalcode

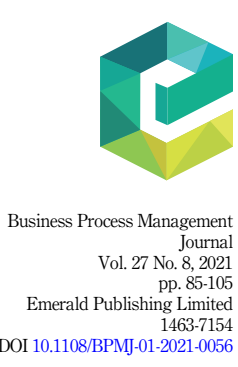


BPMJ 27,8 surrounded the concept. Maybe this has been due to specific operational definitions or general understandings of what counts as productisation having been missing (Hemple et al., 2015). Some attempts to clarify the concept do exist (e.g. Jaakkola, 2011; Harkonen et al., 2015, 2017; Kuula et al., 2018). Nevertheless, empirical evidence has been scarce in the literature.

Productisation of services is referred to have many benefits as numerous authors refer to them (e.g. Aapaoja et al., 2012; Andreini et al., 2015; Chattopadhyay, 2012; Djellal et al., 2013; Harkonen et al., 2015; Heaslip, 2013; Jaakkola, 2011; Mattila et al., 2013; Rajahonka, 2013; Ritala et al., 2013; Simula et al., 2008; Ukko et al., 2011; Valminen and Toivonen, 2012; Valtakoski and Järvi, 2016), whilst no individual research can be identified that would focus on the benefits. Instead, the benefits are often referred to without adequate surrounding discussion. This has resulted in the benefits of service productisation to remain somewhat vague. The discussion has also dispersed across different fields of literature.

In addition, productisation discussion seems to be somewhat bi-directional: One literature stream discusses a rather general process where relevant elements are combined into product-like objects (Flamholtz, 1995; Jaakkola, 2011; Harkonen et al., 2015, 2017; Kuula et al., 2018; Valminen and Toivonen, 2012; Valtakoski and Järvi, 2016), whereas another discusses a new service component marketed as a product, or the evolution of the services component to include a product, often in conjunction with product-service systems (Baines et al., 2007). There is likely to be some overlapping amongst these streams of literature, yet the latter is typically discussed as a reverse approach to the servitisation concept (e.g. Leoni, 2015), potentially causing some confusion. Hence, for clarity, this study focusses on the first stream in its analysis.

This paper explores the benefits of service productisation by utilising evidence from 16 cases that include companies of different sizes from a variety of fields of business and different service types. Some of the analysed companies are globally significant, whereas others are local or regional. Analysing the cases is supported by rather comprehensive literature reviews. This study provides a much-needed empirical approach to service productisation in general, and particularly to its benefits.

\section{Literature review}

Service productisation is increasingly discussed by the literature, whilst also the practitioners seem to be familiar with the concept (Leon and Davies, 2008; Jaakkola, 2011; Harkonen et al., 2017; Valtakoski and Järvi, 2016). The concept is presented to have versatile benefits that are discussed in a dispersed manner across the literature.

Productisation is presented to contribute towards increased effectiveness and profitability in services through systemising the services and resulting in easier and faster routines (Jaakkola, 2011). Also, productisation improving the possibilities of analysing the profitability is seen amongst the benefits (Koskinen et al., 2020). The concept is said to contribute towards competitiveness and efficiency and to facilitate the development of customer understanding of the services (Valminen and Toivonen, 2012; Heaslip, 2013). Customers, employees and others are stated to comprehend the content and familiarise themselves with the services faster once they have been productised (Jaakkola, 2011). In other words, the shared understanding over service products improves (Hannila et al., 2019). Also, the customer core benefit can be identified better (Mustonen et al., 2019). The characteristics of efficiency and effectiveness relate to systematisation and formalisation and relay both the service offering and service processes (Chattopadhyay, 2012; Harkonen et al., 2015; Lehtonen et al., 2015; Valtakoski and Järvi, 2016; Valminen and Toivonen, 2012; Nagy, 2013; Wirtz, 2021; Tuominen and Martinsuo, 2019) and also link to the use of resources. Further, Wirtz (2021) view productisation as means to specify concrete service products, drive innovation and position and differentiate the offering. Service productisation can result in service 
platforms (Löfberg and Akesson, 2018) or standardisation in certain areas of services (Bask et al., 2010; Yuen and Thai, 2017; Ardolinino et al., 2018; Aquilante and VendrellHerrero, 2021). The development of basic processes and structures improve the internal understanding of the services, which further enable the ease of understanding by customers once employees are capable of clearly explaining the service content (Lehtonen et al., 2015; Kuula et al., 2018; Wirtz, 2021). Service productisation provides a common language for stakeholders (Wirtz, 2021). All involved parties can have a clearer understanding of the offering (Leppänen et al., 2020). The service elements being described, the company internally supports employees and others relating to the services (Danson et al., 2005; Harkonen et al., 2017; Simula et al., 2008). This systematisation and concretisation make the services more demonstrable and less intangible (Djellal et al., 2013). Services are made to act more like a product, which can then be produced at higher volumes with scale benefits (Nagy, 2013), also probably explaining the term productisation. Also, increased profitability is linked to service productisation via systematisation (Chattopadhyay, 2012), which is seen to support pricing the services and to help in sustaining unit profit (Gupta, 2011). Pricing is seen to become more concrete and transparent as a result of productisation (Ukko et al., 2011). Pricing logic is developed as a result of service productisation and value can be demonstrated (Kanninen et al., 2017). Also, cost savings are seen particularly due to systematisation (Rajahonka, 2013; Merenheimo, 2016). Figure 1 illustrates a structural logic for a productised service. The commercial side involves the presentation and structural logic that the customers see elements that can be priced. These can include, for example, service configurations and sales items. The technical side involves the structural details of the technical realisation of the service, typically service processes and related resources. Relevant company employees have a view over these elements, as well as the commercial linkages. Customers have a view on certain elements of the technical side only if the service is partially co-created by the customer. Both sides must be linked and functioning version control is necessary. This type of logic allows the same service to be sold, delivered and invoiced.

Productisation reduces the dependency on individual employees (Jaakkola, 2011) and enables division of work (Chattopadhyay, 2012) as a result of service elements being described and less knowledge being required for service provision. Sharing of information across the service development, marketing, sales and service provision seem to be amongst the key premises behind productisation efforts (Simula et al., 2008; Wirtz, 2021). Productisation offers focus and a way of managing emergent conflicts in business relationships (Hemple et al., 2015) whilst enabling transferability of services when services are no longer unique by every aspect (Pelkonen and Valovirta, 2015). Productisation enables addressing the internal heterogeneity (Ritala et al., 2013; Nagy, 2013), which can be problematic, whereas the external variety may still be possible. Productisation is seen to have the potential of helping in establishing a common vocabulary and helping in conflict situations (Valtakoski and Järvi, 2016; Hemple et al., 2015). Also, improved possibilities for

\section{Service \\ productisation in business \\ processes}

87

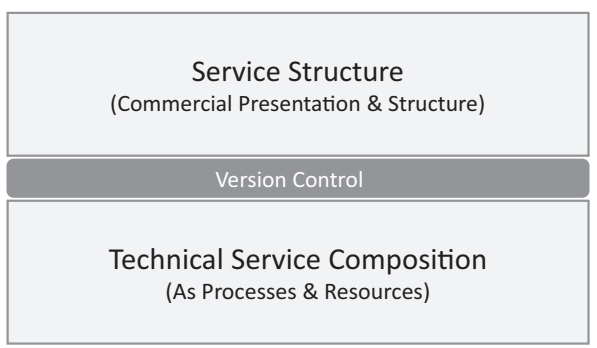

Figure 1.

Productised service 
BPMJ 27,8 cooperation are mentioned amongst the benefits (Aapaoja et al., 2012). The main benefit for companies is potentially the improved manageability of services (Leon and Davies, 2008; Rajahonka, 2013; Harkonen et al., 2017; Jaakkola, 2011), whereas the benefits for customers may include potential improvements in service quality, reduced prices and less time needed for buying the services (Andreini et al., 2015). The service product portfolio management is improved through service productisation (Saunila et al., 2017). Productisation enables a better position to address the overall offering (Wirtz, 2021; Leppänen et al., 2020). In addition, productisation inducing the human ability to evaluate and relate to ongoing actions, structures and their own roles have been mentioned (Lehtonen et al., 2015).

Service productisation is said to improve understanding of the service product structurally (Hannila et al., 2019), and aid in forming service modules (Gremyr et al., 2019). It also clarifies the commercial and technical service offering (Makkonen et al., 2018; Leppänen et al., 2020). Commercial considerations overall are linked to service productisation and seen as relevant to customer interface (Kanninen et al., 2017). Service productisation aids in determining service cost structure (Hannila et al., 2019). Further, the improved structural understanding is seen to help in referring to the constituting service elements as data in company information technology (IT) systems (Lahtinen et al., 2021). The structural understanding is seen to help the data consistency across the IT (Hannila et al., 2019; Koskinen et al., 2020). Overall, structured services provide a frame for various service interactions (Mashhady et al., 2021). These service interactions can be seen to include employee-employee, employee-customer, IT application-IT application, employee-IT, customer-IT, process-process and business-business interactions.

Some potential concerns have also been presented besides presenting the positive aspects. These include tangible, easier to understand services becoming easier to copy by the competition (Djellal et al., 2013; Nagy, 2013), whereas it is the distinctive features that separate from competition, not the systematisation. Some may understand productisation so that no customisation is allowed, causing fears of customer needs being disregarded (Rajahonka, 2013). Similarly, fears over itemisation and providing increasingly less-valuable solutions to customers have been mentioned (Hellström et al., 2016). Also, customers may negatively perceive formalised services if they can believe that their needs and expectations are not adequately considered during the interaction (Andreini et al., 2015), which can be the case for any type of service if relevant interaction is overlooked. Also, new configurations of internal operations and organisational procedures, caused by productisation, are seen as a potential source of indirect negative effects on customer relationships should internal communication and coordination needs be overlooked (Andreini et al., 2015). In addition, service delivery organisations may experience their role diminishing and becoming less challenging intellectually when services do not need to be reinvented every time (Leon and Davies, 2008). The positive concerns entail creating an increased demand for company's services and stretching company resources thin, meaning the company's own success may result in a new set of problems (Flamholtz, 1995, 2002; Flamholtz and Aksehirli, 2000; Flamholtz and Hua, 2002, 2003; Flamholtz and Kurland, 2005).

Table 1 summarises the benefits of service productisation presented by the previous literature.

\section{Methodology}

The following key exploratory research question is derived based on the gaps in research and issues identified in the literature review:

$R Q$. What are the benefits of service productisation, if any, which could be addressed by research to provide further understanding on the productisation concept? 
Benefits presented in the literature

\begin{tabular}{|c|c|c|}
\hline $\begin{array}{l}\text { Facilitate } \\
\text { understanding } \\
\text { internal/external } \\
\text { Heaslip (2013), } \\
\text { Jaakkola (2011), } \\
\text { Kuula } \text { et al. (2018), } \\
\text { Lehtonen } \text { et al. } \\
\text { (2015), Leoni (2019), } \\
\text { Leppänen et al. } \\
\text { (2020), Valminen } \\
\text { and Toivonen } \\
\text { (2012), Wirtz (2021) }\end{array}$ & $\begin{array}{l}\text { Routines Jaakkola } \\
\text { (2011) }\end{array}$ & $\begin{array}{l}\text { Scale benefits } \\
\text { Nagy (2013) }\end{array}$ \\
\hline
\end{tabular}

Reduced

dependency on individuals

Jaakkola (2011)
Effectiveness Quality

Chattopadhyay

(2012), Harkonen

et al. (2015),

Jaakkola (2011),

Lehtonen $e t$ al.

(2015), Nagy

(2013), Tuominen

and Martinsuo

(2019), Valminen

and Toivonen

(2012),

Valtakoski and

Järvi (2016),

Wirtz (2021)

Efficiency

Chattopadhyay

(2012), Heaslip

(2013), Harkonen

et al. (2015),

Lehtonen $e t$ al.

(2015), Nagy

(2013), Tuominen

and Martinsuo

(2019), Valminen

and Toivonen

(2012),

Valtakoski and

Järvi (2016),

Wirtz (2021)
Andreini

et al.

(2015), Ye

(2019)

Price

Andreini

et al.

(2015)

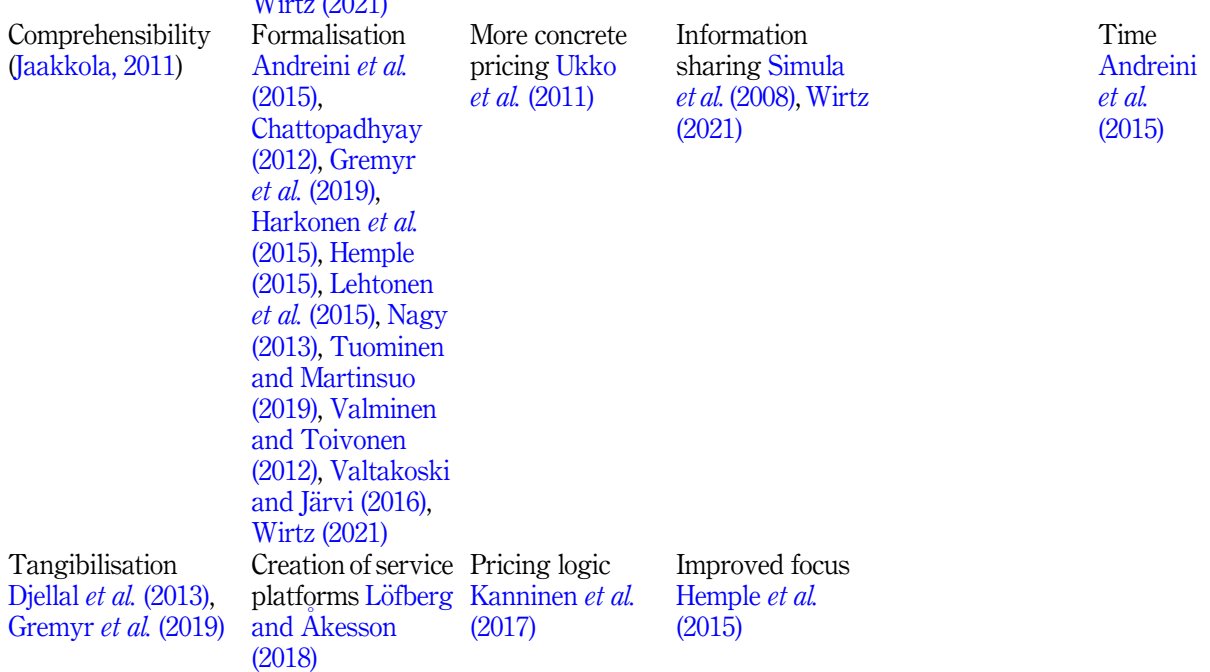

antinsuo

(2019), Valminen

and Toivonen

(2012), Valtakoski

and Järvi (2016),

Wirtz (2021)

Service

productisation

in business

processes

89

(continued)
Table 1.

Benefits of service productisation according to previous 
BPMJ 27,8

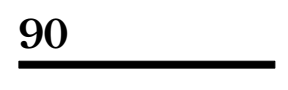

Benefits presented in the literature

\section{Concretisation}

Djellal et al. (2013),

Wirtz (2021)

Identifying core

benefit Mustonen et al. (2019)

Structural understanding

Hannila et al. (2019),

Koskinen et al. (2020), Kuula et al.

(2018), Lahtinen

et al. (2021),

Lehtonen et al.

(2015), Mashhady

et al. (2021), Wirtz

(2021)

Linking to data and

IT Hannila et al.

(2019), Koskinen

et al. (2020),

Lahtinen et al. (2021)

Support for service

interactions

Andreiniet al. (2015),

Mashhady et al.

Table 1.

$$
\begin{aligned}
& \text { Standardisation } \\
& \text { of some service } \\
& \text { elements } \\
& \text { Aquilante and } \\
& \text { Vendrell-Herrero } \\
& \text { (2021), Ardolino } \\
& \text { et al. (2018), Bask } \\
& \text { et al. (2010), Yuen } \\
& \text { and Thai (2017) }
\end{aligned}
$$

Cost savings

Rajahonka

(2013),

Merenheimo

(2016)

Cost structure

Hannila et al.

(2019)

Common
language Wirtz
(2021), Leppänen
et al. (2020)

Marketing and

selling Simula

et al. (2008),

Wirtz (2021)
Transferability

Pelkonen and

Valovirta (2015)

Improved

manageability

Harkonen et al.

(2017), Jaakkola

(2011), Leon and

Davies (2008),

Rajahonka (2013)

Addressing service portfolio

Lahtinen et al.

(2021), Leppänen

et al. (2020),

Saunila et al.

(2017), Wirtz

(2021)

\subsection{Literature review}

A rather comprehensive literature review involving extensive searches is carried out to guide the data analyses. This type of approach has been utilised in a variety of fields by numerous authors and is suitable for multi-disciplinary research. The applied review practice involves standards typical to systematic reviews (Kitchenham, 2004). The review covers previous research on service productisation. Keyword searches were carried out in article databases of Emerald, Google Scholar, Science Direct and Scopus. The keywords used include all the forms and spellings of "productization of services", "service productization" and "productization" "service". The inclusion criteria involve the appearance of the keywords and the paper being published in a peer-reviewed journal. Articles available through the searched databases were included, while any other type of material was excluded. Articles were selected when the keywords appeared in the text but excluded if only appeared in the reference list or biographies. Additional papers were attempted to locate by reviewing the reference lists of the identified papers. The papers were read carefully to analyse the content and decide on the relevance. However, as the terminology on service productisation is yet to be firmly established, some additional supportive searches were also carried out including a few papers 
published in conference proceedings. Any overlapping between findings from different databases was removed. The procedure was repeated to ensure the inclusion of recent articles and avoid missing relevant research. Initially, a total of 569 articles were identified for which the exclusion and inclusion criteria were applied. This resulted in discarding 516 articles due to irrelevancy for the topic or the discussion being limited. A total of 51 journal articles were included in the final analyses. The benefits of service productisation were analysed and descriptive codes were created.

\subsection{Research design}

Case study research design was chosen given the need to gather rich data on the concept of service productisation and its benefits (Collis and Hussey, 2013; Yin, 2013). Exploratory, explanatory and descriptive case studies have been clarified by Yin (2013), allowing us to assume that any of these would be a solid case study approach. Exploratory case study precedes theory building and has the purpose of "uncovering areas for research and theory development" (Stuart et al., 2002). Exploratory investigations relate to situations where the variables and the phenomena are not fully known and understood (Voss et al., 2002). The exploratory approach provides benefits in terms of the understanding that can be reached (Meredith, 1998). Hence, an exploratory case study approach can be seen as appropriate, as rather little in-depth understanding is available in the literature about the concept of service productisation.

Utilising multiple cases can be beneficial to complement the previous studies that fail to discuss service productisation, and particularly its benefits, in a depth that would be necessary to support an issue that is discussed by practitioners but is less focussed on in the scientific literature. According to Eisenhardt and Graebner (2007), the approach allows reaching generic conclusions, which can be beneficial for a less studied concept.

The collection of the secondary data was carried out during 2019-2020, while the cases are based on closely relevant studies realised between 2008 and 2020 on 16 companies. The cases include expert services, care services, maintenance and repair services, hospitality services, IT services and testing services. The companies vary from consultancies, building and construction, elevators and escalators, hospitality, IT, large electronics, to a telecommunications networks company. The cases were selected based on the availability of relevant data. The diversity of businesses and industries allows considering the relevance and prevalence of productisation concept across different fields.

\subsection{Data collection}

Qualitative secondary data are obtained by using previous related studies to find data that are relevant to the topic in question. The utilised data were initially collected for purposes other than analysing the benefits of service productisation for projects that had slightly different aims than this study. The data were, however, recognised to reveal the benefits, which was of interest. Hence the data are referred to as secondary data in this research. The documents and data sets were intentionally identified and carefully read to judge the suitability. As the opportunity of utilising the data were identified and the data were seen to serve the purposes, they were decided to use for analysis. The data contains interview material, different guidelines and company documentation and observations made by those who conducted the original interviews.

Secondary data can be appropriate and beneficial by providing access and visibility over sensitive situations while reducing distortion caused by an imperfect recall and social desirability bias (Harris, 2001). Other advantages include opportunities for research access wider than otherwise possible (Liedtka, 1992), credibility (Nachmias and Nachmias, 1987) and cost (Cowton, 1998). The data can originate from a variety of sources including different documents, reports and published or unpublished research (Harris, 2001). 
BPMJ

27,8

92

\subsection{Data analysis}

Analysing secondary data can be appropriate and allow the researcher to use existing data collected for the purposes of a prior study. New research questions or alternative perspectives can be utilised to pursue interests that vary from the original purpose (Thorne, 1990; Hinds et al., 1997; Szabo and Strang, 1997; Heaton, 2008). Examples of previously published research conducting qualitative analyses of secondary data do exist, composed of interviews, observations and possibly some other evidence in areas such as health research (Gladstone et al., 2007), industry and innovation (Kristinsson and Rao, 2008) and operational research (Samaddar et al., 2006). Hence analysing secondary data can be seen as an appropriate basis for analyses.

The analysis of the content is carried out through qualitative content analysis (Cho and Lee, 2014), which has many characteristics in common with thematic analysis (Neuendorf, 2018). Systematic coding practices have been applied. The analysis was started with a set of $a$ priori codes, which in this study involve the template formed by the literature review, and the benefits of service productisation identifiable from the previous literature. However, these codes were flexible in terms of the researchers willing to modify them, or include new benefits, should they arise from the data. This is a similarity to thematic analysis (Neuendorf, 2018). The analysis focus is on selected aspects that are relevant with a view to the research question (Schreier, 2012). The focus is not on finding relationships amongst the categories, but on extracting categories from data (Cho and Lee, 2014). The categories were revised during the analysis procedure, and should data not be possible to code to priori codes, new categories were introduced. The outcome answers the research question. The use of qualitative content analysis yields a set of categories on the benefits of service productisation. Due to discussing service productisation, the productisation-induced benefits were further categorised based on service components of service offering, processes, service delivery system and overall to provide further meaning for the benefits of productisation.

The practical analysis includes coding the material so that key aspects are flagged, while any remarks are kept separate. Evidence that directly speaks to the studied phenomenon is identified first separately for each case, after which patterns across the cases were sought. The coding and analyses are confirmed by colleagues to avoid researcher bias. The analysis was supported by the understanding obtained from the previous related literature and the resulting analysis frame.

\subsection{Company characteristics}

Table 2 presents a summary of key company information of 16 case companies, which are classified by company size according to the European Union (EU) categorisation. Each company was labelled using a reference code to retain anonymity.

\section{Findings}

Several benefits of service productisation were experienced in the case companies all of which are discussed below:

Productisation formalises the offering and clarifies processes to reduce overlapping work and to increase service quality. This was expressed by an interviewee as "productisation enables the whole service delivery process to gain efficiency by decreasing the amount of variation in the services", "formalisation enhances service provision, their [services] profitability and steady quality". Particularly, company internal processes and ways of working are clarified: "productisation is initiated internally when realising that company's internal processes are not very efficient". This concretises services, enables reproducing the services and further forces the focus more towards service production: "productisation 


\begin{tabular}{|c|c|c|c|c|c|c|}
\hline $\begin{array}{l}\text { Company } \\
\text { label }\end{array}$ & Service type & Business & Turnover & $\begin{array}{l}\text { Company } \\
\text { size* }\end{array}$ & $\begin{array}{c}\# \\
\text { Interviewees } \\
\end{array}$ & $\begin{array}{r}\text { Service } \\
\text { productisation }\end{array}$ \\
\hline L1 & $\begin{array}{l}\text { Care and managed } \\
\text { services }\end{array}$ & Telecom networks & $\begin{array}{l}\text { Tens of } \\
\text { billions } €\end{array}$ & Large & 8 & processes \\
\hline L2 & $\begin{array}{l}\text { Service desk } \\
\text { services }\end{array}$ & $\begin{array}{l}\text { Infrastructure and } \\
\text { construction }\end{array}$ & Billions of $€$ & Large & 9 & \\
\hline L3 & $\begin{array}{l}\text { Maintenance and } \\
\text { repair services }\end{array}$ & Elevators and escalators & $\begin{array}{l}\sim \text { Ten } \\
\text { billion€ }\end{array}$ & Large & 6 & 93 \\
\hline $\mathrm{L} 4$ & IT services & IT & $\begin{array}{l}\text { Tens of } \\
\text { billions } €\end{array}$ & Large & 8 & \\
\hline L5 & Care services & Electronics & $\begin{array}{l}\text { Tens of } \\
\text { billions } €\end{array}$ & Large & 12 & \\
\hline L6 & $\begin{array}{l}\text { Access control } \\
\text { services }\end{array}$ & Access control systems & $\sim 200 \mathrm{M} €$ & Large & 11 & \\
\hline M1 & $\begin{array}{l}\text { Consultancy } \\
\text { services }\end{array}$ & $\begin{array}{l}\text { Management software } \\
\text { business }\end{array}$ & $\sim 10 \mathrm{M} €$ & $\begin{array}{l}\text { Medium- } \\
\text { sized }\end{array}$ & 4 & \\
\hline M2 & Technical services & Federation of municipalities & $\begin{array}{l}\text { Not } \\
\text { disclosed }\end{array}$ & $\begin{array}{l}\text { Medium- } \\
\text { sized }\end{array}$ & 5 & \\
\hline M3 & $\begin{array}{l}\text { Care services for } \\
\text { industrial products }\end{array}$ & Engineering & $\sim 20 \mathrm{M} €$ & $\begin{array}{l}\text { Medium- } \\
\text { sized }\end{array}$ & 4 & \\
\hline M4 & Consulting & Engineering & $<50 \mathrm{M} €$ & $\begin{array}{l}\text { Medium- } \\
\text { sized }\end{array}$ & 6 & \\
\hline M5 & $\begin{array}{l}\text { Building service } \\
\text { systems }\end{array}$ & Building services & $\sim 10 \mathrm{M} €$ & $\begin{array}{l}\text { Medium- } \\
\text { sized }\end{array}$ & 3 & \\
\hline S1 & $\begin{array}{l}\text { Professional } \\
\text { services }\end{array}$ & Planning office (IT) & $\begin{array}{l}\text { Not } \\
\text { disclosed }\end{array}$ & Small & 4 & \\
\hline S2 & $\begin{array}{l}\text { Telecom testing } \\
\text { services }\end{array}$ & $\begin{array}{l}\text { Information and } \\
\text { communications technology } \\
\text { industry (ICT) }\end{array}$ & $\begin{array}{l}\text { Not } \\
\text { disclosed }\end{array}$ & Small & 3 & \\
\hline Mi1 & Hospitality services & Hospitality & $\begin{array}{l}\text { Not } \\
\text { disclosed }\end{array}$ & Micro & 2 & \\
\hline Mi2 & Expert services & Management consulting & $<500 \mathrm{k} €$ & Micro & 2 & \\
\hline Mi3 & Expert services & $\begin{array}{l}\text { Healthcare and } \\
\text { pharmaceuticals }\end{array}$ & $>400 \mathrm{k} €$ & Micro & 3 & $\begin{array}{l}\text { Company information } \\
\text { classified by }\end{array}$ \\
\hline \multicolumn{6}{|c|}{ Note(s): *European Union categorisation } & company size \\
\hline
\end{tabular}

concretised the service and it became easier to reproduce", "[.. .] creating variety the customer can choose ... from formalised modules [.. .]". The formalised service processes particularly support the necessary simplicity and routines that are beneficial for service provision: "[ . .] service and process descriptions ... more routine, formalised service provision that can be set targets and measures [...]". In addition to formalised offering and processes, productisation ensures that services will have clear definitions for necessary tools needed for service provision, including information about essential templates needed for reporting and any required resources. An interviewee described, "[...] defined service concepts that include descriptions on the content and tools needed for service provision, resources and the working methods".

Productisation creates the core structure for services and removes the need to reinvent the service for every customer: "[.. .] the basics do not need to be re-invented every time for each customer, and the time needed is reduced [...]". The core structure for services enables multiplying the services and makes everything faster. Also, approaching customer needs via tailoring seem to be supported by productisation when the service elements are clarified: "selling productised services as tailored is possible as productisation refers to building different types of service modules". Nevertheless, "the value promise is not built from the productised 
BPMJ 27,8

service, but familiarising with the customer and their challenges", based on this customer understanding, the formalised service elements can be better utilised. The service definitions for productised services that must be understood contain information about the benefits and value to customers and about the individual service elements with relevant links to the process. The productised services support internal and external understanding, which are also sought after when considering productisation: "the benefits that are sought include more concrete, easier to understand services". Certain modularisation further supports the manageability, benefit expressed as: "[. . .] improve manageability of the services and increase customer satisfaction". This modularisation helps in communicating with customers about the services. An interviewee described the improved communication as, "we could discuss the actual problem and understand the customer ... and can put something on the table and ask whether this was it [...]". Also, separating service activities to those visible to customers and those visible only to the company support clarifying activities and improve participants' understanding about necessary company contacts, and even the customers' own role: "[... .] their own role is clarified to the customer with possibilities to influence during the service process [...]". For the company itself, productisation entails some mechanisms to obtain feedback about the services and to test them to improve the possibilities of success before to offering them to customers. The possibility for feedback was described as "[ . . ] service tested in a real customer environment. Only this way it would be possible to receive genuine customer feedback on the service, its functions, and practicalities". The feedback further enables working with internal working methods and learning about the service.

Table 3 illustrates the benefits of service productisation drawn from the analysed cases.

The benefits induced by service productisation clearly involve the service offering and relevant service processes as all analysed companies seem to understand the benefit of clarifying/formalising service offerings and processes.

Identifying and defining core service elements was alone experienced beneficial due to benefits in customer interaction and the improved manageability of services: "Services having a specified form enables managing with relevant goals and measures" and "better customer understanding and avoid misunderstandings". This, particularly as the roles of different types of service components, becomes clearer and the resources needed for delivering the services can be known more precisely. The creation of service descriptions is beneficial, as then it is clearly known what is delivered and what the benefits are and what the potential value is for customers. Two interviewees had commented on service descriptions as follows: "The service descriptions should contain information on the benefits and the value to customers.", "Descriptions include pricing principles and method of pricing". Information on which service elements can be combined and how is also vital. Service process descriptions, on the other hand, support the understanding of how service processes will take place, what the resources are and who will be involved, that is, all relevant activities are documented: "Process descriptions include all relevant activities and participants in a service blueprint", "Enable clear understanding on relevant company contact's and emphasise customer's own role" and "Enable better customer understanding, and avoiding misunderstandings".

Productisation also seemed to initiate seeking for customer perspective, as customers were seen to have an essential role in the case of services. In fact, better possibilities for meeting customers' needs were seen as a major benefit of productisation. These, as needs, are used as a basis when defining service elements but also due to improved interaction and addressing any issues via feedback. An interviewee had commented, "Clarifying the service content, or the content of modules will help the customers to choose what they need" and "The company tries to meet the needs of the customers when productising". The value promise and the benefits of service becoming clearer and more understandable and are also amongst the reasons for productised service meeting customer's needs while the improved service quality may also have a role. 


\begin{tabular}{|c|c|c|c|}
\hline Service component & Productisation induced benefit & Recurrence & Service \\
\hline \multirow[t]{20}{*}{ Service offering } & Defining core services & $\begin{array}{l}\text { L3, L4, M5, Mi1, Mi2 and } \\
\text { Mi3 }\end{array}$ & in business \\
\hline & Service descriptions & L2, M4 and M5 & processes \\
\hline & Understanding commercial offering and the features & L6, M1, M5 and Mi3 & \\
\hline & $\begin{array}{l}\text { Improved possibilities for customer benefit } \\
\text { assessment and service development }\end{array}$ & $\mathrm{L} 6, \mathrm{M} 5, \mathrm{~S} 1$ and $\mathrm{S} 2$ & 95 \\
\hline & $\begin{array}{l}\text { Improved linkage between commercial and technical } \\
\text { side of the service }\end{array}$ & $\begin{array}{l}\text { L1, L6, M2, M4, M5, S1, S2, } \\
\text { Mi2 and Mi2 }\end{array}$ & \\
\hline & Support for meeting customer needs & M2, Mi2 and Mi3 & \\
\hline & Service value to customers more understandable & L6, M4 and M5 & \\
\hline & Understanding over sellable features & L6 and M5 & \\
\hline & Understanding generic service & L6, M5 and Mi3 & \\
\hline & $\begin{array}{l}\text { Improved communication internally and towards } \\
\text { outside }\end{array}$ & $\begin{array}{l}\mathrm{L} 1, \mathrm{~L} 4, \mathrm{~L} 5, \mathrm{M} 1, \mathrm{M} 2, \mathrm{~S} 1 \text { and } \\
\text { S2 }\end{array}$ & \\
\hline & Reduced overlapping work & $\begin{array}{l}\text { L1, L2, L3, L4, L5, M2, M4 } \\
\text { and M5 }\end{array}$ & \\
\hline & Easier to understand the cost & $\begin{array}{l}\text { L5, L6, M1, M2, M4, S1, S2, } \\
\text { Mi1 and Mi2 }\end{array}$ & \\
\hline & Easier to sell & $\begin{array}{l}\text { L4, M2, M4, S1, S2, Mi1 and } \\
\text { Mi2 }\end{array}$ & \\
\hline & Support for marketing communication & M4, Mi2 and Mi3 & \\
\hline & Distinction to competition & S1 and Mi2 & \\
\hline & Services become more tangible and concrete & $\begin{array}{l}\text { L4, M1, M2, M3, M4, S1, S2, } \\
\text { Mi2 and Mi3 }\end{array}$ & \\
\hline & Tailoring to customer needs better supported & L6, M1, M4, Mi2 and Mi3 & \\
\hline & Improved understanding over what can be tailored & L6 and M5 & \\
\hline & Improved possibilities to manage services & $\begin{array}{l}\text { L3, L6, M2, M3, M4, S1, S2 } \\
\text { and Mi2 }\end{array}$ & \\
\hline & Managing services with relevant goals and measures & L3, M5 and Mi2 & \\
\hline \multirow{17}{*}{ Processes } & Service process descriptions & $\mathrm{L} 2, \mathrm{M} 4$ and $\mathrm{Mi} 3$ & \\
\hline & Reduced overlapping work & $\begin{array}{l}\mathrm{L} 1, \mathrm{~L} 2, \mathrm{~L} 3, \mathrm{~L} 4, \mathrm{~L} 5, \mathrm{M} 2, \mathrm{M} 4 \\
\text { and M5 }\end{array}$ & \\
\hline & Less unnecessary re-engineering of features & L6 and M5 & \\
\hline & $\begin{array}{l}\text { Improved possibilities for further service } \\
\text { development }\end{array}$ & $\mathrm{M} 5, \mathrm{~S} 1$ and $\mathrm{S} 2$ & \\
\hline & Meeting customer needs easier & $\begin{array}{l}\text { L1, M2, M4, M5, S1, S2, Mi1 } \\
\text { and Mi2 }\end{array}$ & \\
\hline & Customers can better understand the service value & $\mathrm{M} 2, \mathrm{Mi} 2$ and $\mathrm{Mi} 3$ & \\
\hline & Improved communication & $\begin{array}{l}\mathrm{L} 1, \mathrm{~L} 2, \mathrm{~L} 4, \mathrm{M} 1, \mathrm{M} 2, \mathrm{~S} 1 \text { and } \\
\text { S2 }\end{array}$ & \\
\hline & Easier to price the services & $\begin{array}{l}\text { L5, M1, S1, S2, M2, M4, Mi1 } \\
\text { and Mi2 }\end{array}$ & \\
\hline & Easier to sell the services & $\begin{array}{l}\text { L4, L6, M2, M4, S1, S2, Mi1, } \\
\text { Mi2 and Mi3 }\end{array}$ & \\
\hline & Support marketing communication & M4 and Mi2 & \\
\hline & Distinction to competition & M5, S1 and Mi2 & \\
\hline & Tangible and concrete service processes & $\begin{array}{l}\text { L4, M1, M2, M3, M4, M5, S1, } \\
\text { S2 and Mi2 }\end{array}$ & \\
\hline & Simplicity and routines for service provision & L4, M1, M3, S2 and Mi2 & \\
\hline & Possibilities to manage services improve & $\begin{array}{l}\text { L3, M2, M3, M4, S1, S2 and } \\
\text { Mi2 }\end{array}$ & \\
\hline & $\begin{array}{l}\text { Managing service provision with relevant goals and } \\
\text { measures }\end{array}$ & L3, M5 and Mi2 & \\
\hline & Time taken by service provision & $\mathrm{L} 4, \mathrm{M} 4$ and $\mathrm{Mi} 2$ & \\
\hline & & (continued) & $\begin{array}{r}\text { Benefits of service } \\
\text { productisation }\end{array}$ \\
\hline
\end{tabular}


BPMJ 27,8

96
Overall

Service component
$\begin{aligned} & \text { Service delivery system } \\ & \text { (resources) }\end{aligned}$

Productisation induced benefit

Possibilities of using experienced employees for other tasks

Less dependency on individuals

Time taken by service provision

Reduced overlapping work

Possible to sell, deliver and invoice

Distinction to competition

Focus on customer's needs and desired features

Possibilities to manage services with relevant goals and measures

Service quality improvement

Distinction between standard and customer-specific

Improved understanding, internal and external

Improved service interactions

Company renewal through innovation

Lifecycle considerations enabled

Aid in profitability assessment

Possibilities for further development

Improve management decision-making

Table 3.
Recurrence

M1, Mi2 and Mi3

$\mathrm{M} 1$ and Mi3

L4, M4, Mi2 and Mi3

L1, L2, L3, L4, L5, L6, M1, M3 and M5

L6 and M5

$\mathrm{S} 1$ and $\mathrm{Mi} 2$

L6 and M5

L3 and Mi2

M1 and M4

L6 and M5

L6 and M4

L6 and Mi3

L6, M5 and Mi3

$\mathrm{M} 5$ and S1

M1, M2, S1 and Mi2

M4 and Mi2

L6 and M3

L3 and M2

Communicating with customers is seen to be supported by productisation, and it is seen to improve also company internally along with formalisation, defined components and processes providing a basis for communication: "Helps in communicating with customers and help them [customers] to choose, and better understand what they want" and "Easier to communicate with customers thereby promoting customer satisfaction". As a consequence, selling the services may become easier when service elements are combined with ease based on gained understanding over the need and the suitability checked with customers without having to go through a major service rethinking. The systematic and understandable service offering that is easier to communicate is seen to be amongst the enablers for the ease of selling: "clearly divided offerings make selling easier as customers always have their view on how they wish to see the service". Thus, the same also applies to marketing communication.

Service productisation is seen to help in profitable pricing, aided significantly by clarified service content: "Productisation can help in understanding the service value, and enable value-based pricing models" and "Service modules are priced to cover cost and have a profit margin". The service descriptions can contain information on pricing principles and methods and certain guidelines for how the elements can be combined. Also, distinction to competition is enabled by supportive services that are understood as their own components. The tangibility of services aside from structure is supported by describing the service elements and identifying which elements are core and which are additional: "Different service elements are named and described to make it [service] more tangible". The time taken by service provision was also referred to as a benefit but was not specified in detail, other than no need to completely rethink the service every time. The productised services were seen to act as a platform for further development via, for example, the service process descriptions, improved cooperation and through improved understanding over different roles. Also, new ideas were seen as possible through improved comprehension. Productisation supporting taking service product strategy into practice was seen as a benefit but was not otherwise further addressed in any of the cases: "takes service product 
and communication strategy into practice". Neither was the service strategy self-evident nor directly addressed. Nevertheless, service strategy was mentioned together with its influence on the sales function.

Improved understanding of the service is seen as one of the main benefits of productisation whilst particularly beneficial internally in terms of more experienced personnel being able to focus on other matters: "experienced personnel can move onto new projects". A better understanding of the service value enables utilising value-based pricing models. Thus, one of the more important benefits entails better possibilities to manage the services: "Enables managing with relevant goals and measures" and "Clarifies cost structure, and improves management decision-making". The use of relevant goals and measures is pointed to become possible as a result of simplicity of routines and services having a systematised form that can be linked to resources: "Provides simplicity and routines for providing the services" and "[...] with relevant goals and measures." This is seen to result in new possibilities for follow-up and measurement. Also, new possibilities of guiding the operational work arise and even increased focus on service lifecycle may become possible. The clarified cost structure acts as a source of improved management decision-making. Figure 2 synthesises the essence of service productisation.

Service productisation relates to the composition of service offering, which when structured into a manageable form has a certain structural representation. This structural representation involves the technical side of the service that can be manifested as service processes, sub-processes and related resources. This side specifically, and the related inner logic are intended to be visible to the company only unless some services are co-created, which would partially open visibility for customers. The commercial structure can be manifested as service configurations and sales items, visible to customers, as elements that can be priced and explained. Each service-sales item should be linked to the version of the provided service to enable possibilities to manage change. The commercial and technical side must be connected. The representation of the productised service that has a structural logic can be represented in company IT systems that handle data, as the defined service elements can be referred to as data. The way each company handle services and the related structure in their IT systems can have certain company specifics. The IT systems link to company business processes. The business processes, IT, data and the offering form a logical whole. There are various related interactions, employee-IT, employee-employee, customeremployee, customer-IT, IT-IT and process-process that may influence the service productisation, service design and development, marketing and sales or the service provision. These are necessary to address and a clear logic must exist to succeed with services and maintain the focus on what is sold, delivered and invoiced so that the service

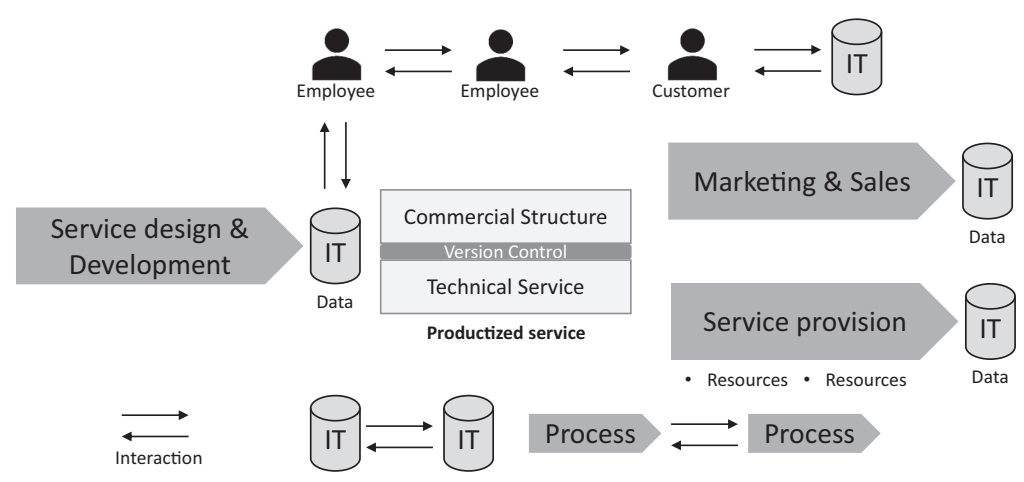

Figure 2. Service productisation results in clarity, a more formalised offering, processes and delivery system, involving a variety of related benefits and improve the scope of what is sold, delivered and invoiced 
BPMJ

27,8

remains the same throughout and the representation does not create additional challenges by changing along the process.

Finding: Service productisation seems to have significance in terms of the service offering, processes and the service delivery system, affecting a variety of company activities, including service development, service design, operations and sales and marketing. The benefits of service productisation have been articulated variably, but all seem to aim towards improved effectiveness, consistency, value, service interactions and meeting customer needs.

\section{Discussion}

A service product is a defined service or an intangible offering provided as a service, one that is possible to sell and deliver to satisfy customers' needs, something that customers can place an order for, one that can be invoiced by the provider. Anything related to the service that does not meet the criteria is not a service product. Service productisation has a role in relation to service products, impacting the service offering, service processes and the related resources. Service productisation aims at being able to deal with the service as the same service product over service interactions and the service lifecycle. Previous service productisation discussion has remained somewhat dispersed, potentially due to having significance across a variety of activities, including service development, service design, operations and sales and marketing, covering both commercial and technical perspectives. The benefits of service productisation, however, have remained to be aggregated. The benefits of service productisation are important to be perceived to further understand the productisation concept and its value. Regardless of the variety in the articulation of the benefits, they all seem to aim towards improved effectiveness, consistency, value and meeting customer needs. Also, the service interactions of different nature are supported by service productisation. Previously, the certain ambiguity has caused clear operational understanding over service productisation to be missing. Nevertheless, productising services successfully has value to ensure uniformity on services in terms of the scope of what is sold, delivered and invoiced.

This study provides a unique contribution to the service productisation discussion by presenting evidence from 16 cases and exploring and aggregating the related benefits. The findings support the previous literature that indicates some of the service productisation benefits by bringing the benefits together (e.g. Aapaoja et al., 2012; Andreini et al., 2015; Chattopadhyay, 2012; Djellal et al., 2013; Harkonen et al., 2015, 2017; Heaslip, 2013; Jaakkola, 2011; Kuula et al., 2018; Mattila et al., 2013; Rajahonka, 2013; Ritala et al., 2013; Simula et al., 2008; Ukko et al., 2011; Valminen and Toivonen, 2012; Valtakoski and Järvi, 2016; Wirtz, 2021). However, a new contribution is provided by conveying the understanding of the significance for a variety of company activities and how they all should have the same scope in order to service productisation to be truly successful. Hence, understanding the benefits of service productisation to aim towards improved effectiveness, consistency, value and meeting customer needs can support enhancing the operational understanding of service productisation. The order of importance of operating processes such as selling, delivering and managing the customer service has been assessed (Cragg and Mills, 2011); however, this study contributes by emphasising the benefit of successful productisation by highlighting the importance of service scope remaining the same through sold, delivered and invoiced service. Further, Bask et al. (2010) is complemented by strengthening the link between operational-level business processes and service productisation. Service-related capabilities (Kanninen et al., 2017) are complemented by strengthening the link between technical capabilities and the commercial side of services in the business process context. New contribution is provided by attempting to combine the understanding of the benefits and discussing these in relation to service offering, service processes and the service delivery system. The connection of service processes, customer priorities, organisational goals and 
utilisation of resources (Paltayian et al., 2017) is supported by this presented linkage. The benefits of service productisation can be identified to impact or link to the important service components in a variety of ways. Simultaneously, it is clear how service products are not considered enough through a clear service product structure or a decomposition logic. Hence, it appears that companies are not necessarily in full control of the service structure, which hinders the possibilities to effectively manage the services. The deficiency is apparent in most literature discussing productisation. Service structure and decomposition logic considerations would allow better service product portfolio management and addressing the service lifecycle and the services structurally.

Productisation of services provides benefits by providing clarity for service offering through defining the core services and the service elements, further enabling to form the service product. Productisation also provides clarity to the service processes and supports the resource considerations. The observed benefits of service productisation are supported by the literature in terms of clarifying the service offering and the related processes, and the resulting improved internal and external understanding (Jaakkola, 2011; Valminen and Toivonen, 2012; Mattila et al., 2013; Chattopadhyay, 2012; Djellal et al., 2013; Ritala et al., 2013; Rajahonka, 2013; Simula et al., 2008; Aapaoja et al., 2012; Heaslip, 2013; Harkonen et al., 2015, 2017; Andreini et al., 2015; Ukko et al., 2011; Valtakoski and Järvi, 2016; Wirtz, 2021). The newness of this study lies in observing the benefits more widely, in relation to the service components of offering, processes and resources. The resource related benefits include reduced dependency on individuals, reduction in overlapping work and reduction in time required for service provision. Nevertheless, even though the relation of productisation to resources is apparent in the literature (Jaakkola, 2011; Chattopadhyay, 2012), the discussion in conjunction with service productisation has much room for further research.

The degree of customer involvement seems to vary amongst services in different business fields, which, however, did not seem to have much influence on how service productisation is seen or how the benefits are conveyed. Another observation is that the importance of customers' understanding over services is further emphasised in those services that are particularly knowledge-intensive. Overall, service productisation seems to have similar aims and benefits, regardless of the service type or business in question.

In line with Hemple et al. (2015), productisation provides a focus for the services. This focus and the clarity over services result in improved communication, both internal and towards outside, which play a part in the possibilities of managing services. Also, in line with Chattopadhyay (2012), more stable service quality is possible via well-defined services and service production processes. Further, in line with multiple authors and well evident across the cases, service productisation improves the effectiveness, efficiency and competitiveness via formalising and systematising services (Jaakkola, 2011; Valminen and Toivonen, 2012; Ritala et al., 2013; Harkonen et al., 2017; Kuula et al., 2018).

There were some indications amongst the cases that productisation can aid in profitability considerations, for which also the literature provides support by pointing how profitability can be reached via systematisation and defined, systematised and concretised service (Jaakkola, 2011; Chattopadhyay, 2012; Hannila et al., 2019). Nevertheless, this benefit could reach much more solid support via service structure and decomposition logic considerations. Albeit, already, the clarified and defined service offering and processes together, and the resulting improved understanding over services and their value makes pricing of services easier and is supported by both the cases and the literature (Chattopadhyay, 2012; Harkonen et al., 2015; Ukko et al., 2011). In general, both the cases and the literature recognise that there might be new possibilities for better management of services as a result of service productisation (Chattopadhyay, 2012; Harkonen et al., 2015; Rajahonka, 2013).

The findings of this study support Iman (2016) in modularity from the service perspective by being closely connected to service productisation. Also, Leoni (2015) is supported in 
BPMJ

27,8 productisation decomposing service components into combinable modules. The discussion of service productisation being dispersed across a variety of fields, including operations, management and service marketing and sales would probably provide possibilities for further research, whereas this study supports Goldstein et al. (2002) in service offering potentially being the common link between new service development, service design and service innovation. The service offering being a common denominator could explain the discussion spanning over a variety of fields and the authors not having managed to clearly position to a certain discussion. The operations perspective on service productisation, however, requires further studies. Nevertheless, regardless of this study exploring the benefits of service productisation, the individual benefits require thorough further empirical studies, to deeply focus on the logic and reasoning behind them. In general, the concept of service productisation is relatively new and deserves wide-based attention.

\section{Conclusions}

Service productisation has significant potential benefits that involve the service offering, processes and resources and affect a variety of company activities. The prior literature has provided some indications, but the specific focus on the benefits has been lacking alongside a certain unclarity on what counts as service productisation. This study explores the benefits of service productisation through literature and analysing 16 cases to provide further understanding.

The main benefits of service productisation involve the clarity and structure of the service, the service processes and providing a basis for service interactions of different nature. Productisation can also be seen as the formalisation of the core service elements that are defined and described, aside from any additional elements. The service processes are clarified by mapping different activities as well as elucidating different responsibilities. Both allow more effective focus on the resources. Internal and external understanding of the services is enhanced as a result of the clarity on what constitutes a service product and which activities are relevant. Similar activities are discussed under different methodologies, whereas service productisation provides the umbrella term for a set of methodologies for addressing service products. Service quality may improve as a result of productisation, as well as managing and pricing the services, which is supported as understanding on how different service components can be combined becomes clearer, and the logic of the service does not need to be reconsidered separately for each customer. Tailoring the services for customer needs is supported as a reference point that exists, as well as the value to customers is easier to assess. Company internally, services can be seen to become more manageable as a result of productisation. Important in services, however, is also to pay particular attention to customer interaction, as it has a direct influence on how customers perceive the service. Service productisation provides a platform for effective customer interaction that also plays a role in customer's service experience.

Practitioners benefit from the findings by receiving support to understand how service productisation have a wide influence and affects a variety of company activities, including service development, service design, operations and sales and marketing. It is vital to understand how service productisation is successful once the service has the same scope in terms of what is sold, delivered and invoiced. These should be the same regardless of the system where the service product is addressed or the nature of service interactions. Business processes are necessary to systematically organise customer value creation. The primary activities contribute directly to value creation. A coherent whole is desirable, while the business processes link directly to company IT systems, data and the offering, the products or services. The processes cannot perform unless the company offering is under control. Service productisation provides systematics to bring the services under control and improve their manageability. This involves considering the services through the logic of commercial 
and technical structure. Business processes also link company operations to customers' requirements, highlighting the effective interaction with customers, aside from any other relevant interactions that may influence the service provision. Certain formalisation might be necessary to gain clarity over the service offering and systematise processes as the service offering links to the processes and the entire delivery system. Also, adapting to changing business requirements and improving efficiency is only possible if the offering is under control. Service offering is likely not under control if it has not been productised. From the perspectives of effectiveness and efficiency, it is beneficial that the same service that is sold is also delivered, not something else. The same applies to invoicing the service. Service structure will have an impact on supply chain considerations, and the service processes and resources are an essential part of the technical side of the service. Hence, it is important to obtain an understanding of the benefits of service productisation in conjunction with the service concept, processes and resources to have a frame of reference for service considerations. The identified deficiencies in discussing service productisation may also be beneficial when seeking directions for improvements in managing services. It is important for managers to perceive what counts as a service product, how it is constituted, also structurally, and what the benefits of productising are, to better manage the services.

The limitations of this study include utilising secondary data for the purposes of this study when the focus of the original data collection was not the one by this study but related purposes. This, however, enabled to potentially be less biased regarding the goals of the study. Also, the analysis has been qualitative by nature, preventing testing the identified benefits by the means of statistical tests. The capabilities of the researchers to make the right conclusions based on the evidence also pose potential limitations; however, multiple persons have confirmed the findings, which make incorrect interpretations less likely. Also, the number of cases reduces the significance of individual ones, while similar findings across the cases repeat. The potential deviations in benefits and their type between different types of services have not been studied, but the study attempted to find similarities and not possible conflicts as such. The interrelations of the service productisation-induced benefits have not been studied. The type of conclusion available through the analysis is limited to developing categories or themes in terms of benefits of service productisation and providing meaning to $\mathrm{a}$ certain degree. The data analysis did not seek saturation but was based on availability. Further studies are needed to further clarify the inner logic. Future research, aside from addressing the deficiencies of this study could aim to provide deep evidence and descriptions by using primary cases particularly designed to focus on service productisation. Most importantly, considering service productisation from the perspective of service structure, or decomposition logic would be needed to address service product portfolios. This type of approach could include considerations over service lifecycle and service structure layers with a specific perspective on service productisation. This type of structure/decomposition logicbased approach would have the potential of taking managing services to a new level. Also, the specific mechanism of achieving the identified benefits of service productisation in terms of service offering, service structure, service processes and resources should be studied further. An in-depth analysis of companies' best practices and lessons learned to reach the identified benefits could be valuable to strengthen the understanding of service productisation and its benefits. The collaboration of the benefits to achieve organisational efficiency, effectiveness, consistency, value and meeting customer needs might also provide interesting research avenues for future focus.

\section{References}

Aapaoja, A., Kujala, J. and Pesonen, L.T.T. (2012), "Productization of university services", International Journal of Synergy and Research, Vol. 1 No. 1, pp. 89-106. 
BPMJ 27,8
Andreini, D., Salo, J., Wendelin, R., Pezzotta, G. and Gaiardelli, P. (2015), "From a service-dominant logic to a good-dominant logic: consequences for the buyer-seller relationships of a corporate bank", IMP Journal, Vol. 9 No. 3, pp. 250-266.

Aquilante, T. and Vendrell-Herrero, F. (2021), "Bundling and exporting: evidence from German SMEs", Journal of Business Research, Vol. 132, pp. 32-44.

Ardolino, M., Rapaccini, M., Saccani, N., Gaiardelli, P., Crespi, G. and Ruggeri, C. (2018), "The role of digital technologies for the service transformation of industrial companies", International Journal of Production Research, Vol. 56 No. 6, pp. 2116-2132.

Baines, T.S., Lightfoot, H.W., Evans, S., Neely, A., Greenough, R., Peppard, J., Roy, R., Shehab, E., Braganza, A., Tiwari, A., Alcock, J.R., Angus, J.P., Bastl, M., Cousens, A., Irving, P., Johnson, M., Kingston, J., Lockett, H., Martinez, V., Michele, P., Tranfield, D., Walton, I.M. and Wilson, H. (2007), "State-of-the-art in product-service systems, Part B", Journal of Engineering Manufacture, Vol. 221 No. 10, pp. 1543-1552.

Bask, A.H., Tinnilä, M. and Rajahonka, M. (2010), "Matching service strategies, business models and modular business processes", Business Process Management Journal, Vol. 16 No. 1, pp. 153-180.

Chattopadhyay, N. (2012), "Productisation of service: a case study", International Journal of Advanced Computer Science and Applications, Vol. 3 No. 12, pp. 197-201.

Cho, J.Y. and Lee, E.H. (2014), "Reducing confusion about grounded theory and qualitative content analysis: similarities and differences", The Qualitative Report, Vol. 19, pp. 1-20.

Collis, J. and Hussey, R. (2013), Business Research, 4th ed., Palgrave Macmillan, Basingstoke.

Cowton, C.J. (1998), "The use of secondary data in business ethics research", Journal of Business Ethics, Vol. 17 No. 4, pp. 423-434.

Cragg, P. and Mills, A. (2011), "IT support for business processes in SMEs", Business Process Management Journal, Vol. 17 No. 5, pp. 697-710.

Danson, M., Helinska-Hughes, E., Hughes, M. and Whittam, G. (2005), "National and local agency support for Scottish SME internationalisation activity: lessons for small transition economies", International Journal of Entrepreneurship and Small Business, Vol. 2 No. 4, pp. 312-330.

Djellal, F., Gallouj, F. and Miles, I. (2013), "Two decades of research on innovation in services: which place for public services?”, Structural Change and Economic Dynamics, Vol. 27, pp. 98-117.

Eisenhardt, K.M. and Graebner, M.E. (2007), "Theory building from cases: opportunities and challenges", Academy of Management Journal, Vol. 50 No. 1, pp. 25-32.

Flamholtz, E. (1995), "Managing organizational transitions: implications for corporate and human resource management", European Management Journal, Vol. 13 No. 1, pp. 39-51.

Flamholtz, E.G. (2002), "Towards an integrative theory of organizational success and failure: previous research and future issues", International Journal of Entrepreneurship Education, Vol. 1 No. 3, pp. 297-320.

Flamholtz, E.G. (2005), "Strategic organizational development, infrastructure, and financial performance: an empirical investigation", International Journal of Entrepreneurship Education, Vol. 3 No. 2, pp. 117-142.

Flamholtz, E.G. and Aksehirli, Z. (2000), "Organizational success and failure: an empirical test of a holistic model", European Management Journal, Vol. 18 No. 5, pp. 488-498.

Flamholtz, E. and Hua, W. (2002), "Strategic organizational development and the bottom line: further empirical evidence", European Management Journal, Vol. 20 No. 1, pp. 72-81.

Flamholtz, E. and Hua, W. (2003), "Searching for competitive advantage in the black box", European Management Journal, Vol. 21 No. 2, pp. 222-236.

Gladstone, B.M., Volpe, T. and Boydell, K.M. (2007), "Issues encountered in a qualitative secondary analysis of help-seeking in the prodrome to psychosis", Journal of Behavioral Health Services and Research, Vol. 34 No. 4, pp. 431-442. 
Goldstein, S.M., Johnston, R., Duffy, A. and Rao, J. (2002), "The service concept: the missing link in service design research?", Journal of Operations Management, Vol. 20 No. 2, pp. 121-134.

Gremyr, I., Valtakoski, A. and Witell, L. (2019), "Two routes of service modularization: advancing standardization and customization”, Journal of Services Marketing, Vol. 33 No. 1, pp. 73-87.

Gupta, V. (2011), "Corporate response to global financial crisis: a knowledge-based model”, Global Economy Journal, Vol. 11 No. 2, pp. 1524-5861.

Hannila, H., Koskinen, J., Harkonen, J. and Haapasalo, H. (2019), "Product-level profitability: current challenges and preconditions for data-driven, fact-based product portfolio management", Journal of Enterprise Information Management, Vol. 33 No. 1, pp. 214-237.

Harkonen, J., Haapasalo, H. and Hanninen, K. (2015), "Productisation: a review and research agenda", International Journal of Production Economics, Vol. 164, pp. 65-82.

Harkonen, J., Tolonen, A. and Haapasalo, H. (2017), "Service productisation: systematising and defining offering”, Journal of Service Management, Vol. 28 No. 5, pp. 936-971.

Harris, H. (2001), "Content analysis of secondary data: a study of courage in managerial decision making”, Journal of Business Ethics, Vol. 34 No. 3, pp. 191-208.

Heaslip, G. (2013), "Services operations management and humanitarian logistics", Journal of Humanitarian Logistics and Supply Chain Management, Vol. 3 No. 1, pp. 37-51.

Heaton, J. (2008), "Secondary analysis of qualitative data: an overview", Historical Social Research, Vol. 33 No. 3, pp. 33-45.

Hellström, M., Wikström, R., Gustafsson, M. and Luotola, H. (2016), "The value of project execution services: a problem and uncertainty perspective", Construction Management and Economics, Vol. 34 Nos 4-5, pp. 272-285.

Hemple, G., Finch, J. and Pasternak, O. (2015), "Productization as a service: innovation through standards in B2B relationships", ISPIM Conference Proceedings: The International Society for Professional Innovation Management (ISPIM). The XXVI ISPIM Conference, June 14-17, 2015, Budapest, Hungary, pp. 1-42.

Hinds, P.S., Vogel, R.J. and Clarke-Steffen, L. (1997), "The possibilities and pitfalls of doing a secondary analysis of a qualitative data set", Qualitative Health Research, Vol. 7 No. 3, pp. 408-424.

Iman, N. (2016), "Modularity matters: a critical review and synthesis of service modularity", International Journal of Quality and Service Sciences, Vol. 8 No. 1, pp. 38-52.

Jaakkola, E. (2011), "Unraveling the practices of 'productization' in professional service firms", Scandinavian Journal of Management, Vol. 27 No. 2, pp. 221-230.

Kanninen, T., Penttinen, E., Tinnilä, M. and Kaario, K. (2017), "Exploring the dynamic capabilities required for servitization: the case process industry", Business Process Management Journal, Vol. 23 No. 2, pp. 226-247.

Kitchenham, B. (2004), Procedures for Performing Systematic Reviews, Technical Report No. TR/SE0401, Keele University, Keele, Staffordshire.

Koskinen, J., Mustonen, E., Harkonen, J. and Haapasalo, H. (2020), "Product-level profitability analysis and decision-making: opportunities of IT application-based approach", International Journal of Product Lifecycle Management, Vol. 12 No. 3, pp. 210-225.

Kristinsson, K. and Rao, R. (2008), "Interactive learning or technology transfer as a way to catch-up? Analysing the wind energy industry in Denmark and India", Industry and Innovation, Vol. 15 No. 3, pp. 297-320.

Kuula, S., Haapasalo, H. and Tolonen, A. (2018), "Cost-efficient co-creation of knowledge intensive business services”, Service Business, Vol. 12 No. 4, pp. 779-808.

Lahtinen, N., Mustonen, E. and Harkonen, J. (2021), "Commercial and technical productization for factbased product portfolio management over life-cycle", IEEE Transactions on Engineering Management, Vol. 68 No. 6, pp. 1826-1838, doi: 10.1109/TEM.2019.2932974.

\section{productisation in business processes}


BPMJ 27,8

Lehtonen, M.H., Jarvi, K. and Tuominen, T. (2015), "Reflexivity in the 'productisation' of services", International Journal of Work Innovation, Vol. 1 No. 2, pp. 161-184.

Leon, N. and Davies, A. (2008), "Managed service paradox", IBM Systems Journal, Vol. 47 No. 1, pp. 153-166.

Leoni, L. (2015), "Servitization and Productization: two faces of the same coin?", Proceedings of 25th annual RESER Conference, Copenhagen, Denmark, September 10-12, 2015, B1, pp. 1-18.

Leoni, L. (2019), "Productisation as the reverse side of the servitisation strategy", International Journal of Business Environment, Vol. 10 No. 3, pp. 247-269.

Leppänen, T., Mustonen, E., Saarela, H., Kuokkanen, M. and Tervonen, P. (2020), "Productization of industrial side streams into by-products - case: fiber sludge from pulp and paper industry", Journal of Open Innovation: Technology, Market, and Complexity, Vol. 6 No. 4, p. 185.

Li, A.Q., Kumar, M., Claes, B. and Found, P. (2020), "The state-of-the-art of the theory on ProductService Systems", International Journal of Production Economics, Vol. 222, 107491.

Liedtka, J.M. (1992), "Exploring ethical issues using personal interviews", Business Ethics Quarterly, Vol. 2 No. 2, pp. 161-181.

Löfberg, N. and Åkesson, M. (2018), "Creating a service platform - how to co-create value in a remote service context", Journal of Business and Industrial Marketing, Vol. 33 No. 6, pp. 768-780.

Makkonen, H., Nordberg-Davies, S. and Olkkonen, R. (2018), "Shopping for items' or 'Partnering for Performance'? A framework of purchasing practices for value co-creation in post-outsourcing buyer-supplier relationships", Journal of Business and Industrial Marketing, Vol. 33 No. 7, pp. 1027-1036.

Mashhady, A., Khalili, H. and Sameti, A. (2021), "Development and application of a service designbased process for improvement of human resource management service quality", Business Process Management Journal, Vol. 27 No. 2, pp. 459-485.

Mattila, O., Toppinen, A., Tervo, M. and Berghäll, S. (2013), "Non-industrial private forestry service markets in a flux: results from a qualitative analysis on Finland”, Small-scale Forestry, Vol. 12 No. 4, pp. 559-578.

Meredith, J. (1998), "Building operations management theory through case and field research", Journal of Operations Management, Vol. 16 No. 4, pp. 441-454.

Merenheimo, P.K. (2016), "The good, the bad and the ugly: societal understandings framing opportunities for female entrepreneurship in care", International Journal of Innovation and Regional Development, Vol. 7 No. 2, pp. 77-96.

Mustonen, E., Tolonen, A., Harkonen, J. and Haapasalo, H. (2019), "Constructing a joint product portfolio to support commercial cooperation", International Journal of Management, Knowledge and Learning, Vol. 8 No. 1, pp. 3-23.

Nachmias, D. and Nachmias, C. (1987), Research Methods in the Social Sciences, 3rd ed., St. Martin's Press, New York, NY, p. 589.

Nagy, S. (2013), "Service pyramid concept of knowledge intensive business services in the small and Medium sized enterprises sector", International Journal of Advanced Computer Science and Applications, Vol. 4 No. 11, pp. 103-108.

Neuendorf, K.A. (2018), "Content analysis and thematic analysis", in Brough, P. (Ed.), Advanced Research Methods for Applied Psychology; Design, Analysis and Reporting, Routledge, New York, NY, pp. 211-223.

Paltayian, G., Gotzamani, K.D., Georgiou, A.C. and Andronikidis, A. (2017), "Aligning customer requirements and organizational constraints to service processes and strategies", Business Process Management Journal, Vol. 23 No. 5, pp. 1018-1042.

Pelkonen, A. and Valovirta, V. (2015), "Can service innovations be procured? An analysis of impacts and challenges in the procurement of innovation in social services", The European Journal of Social Science Research, Vol. 28 No. 3, pp. 384-402. 
Rajahonka, M. (2013), "Views of logistics service providers on modularity in logistics services", International Journal of Logistics Research and Applications, Vol. 16 No. 1, pp. 34-50.

Ritala, P., Hyötylä, M., Blomqvista, K. and Kosonen, M. (2013), "Key capabilities in knowledgeintensive service business", The Service Industries Journal, Vol. 33 No. 5, pp. 486-500.

Samaddar, S., Nargundkar, S. and Daley, M. (2006), "Inter-organizational information sharing: the role of supply network configuration and partner goal congruence", European Journal of Operational Research, Vol. 174 No. 2, pp. 744-765.

Saunila, M., Rantala, T. and Ukko, J. (2017), "Characteristics of customer value creation in digital services”, Journal of Service Science Research, Vol. 9, pp. 239-258.

Schreier, M. (2012), Qualitative Content Analysis in Practice, Sage, Thousand Oaks, California, CA.

Simula, H., Lehtimäki, T. and Salo, J. (2008), "Re-thinking the product - from innovative technology to productized offering", Proceedings of the 2008 International Society for Professional Innovation Management Conference (XIX ISPIM), Tours, France, June 15-18.

Stuart, I., McCutcheon, D., Handfield, R., McLachlin, R. and Samson, D. (2002), "Effective case research in operations management: a process perspective", Journal of Operations Management, Vol. 20 No. 5, pp. 419-433.

Szabo, V. and Strang, V.R. (1997), "Secondary analysis of qualitative data", Advances in Nursing Science, Vol. 20 No. 2, pp. 66-74.

Thorne, S. (1990), "Secondary analysis in qualitative research: issues and implications", in Morse, J.M. (Ed.), Critical Issues in Qualitative Research Methods, Sage, London.

Tuominen, T. and Martinsuo, M. (2019), "Employees' agency in the formalisation of knowledgeintensive business service processes: a cross-case comparison", Journal of Service Theory and Practice, Vol. 29 No. 1, pp. 45-70.

Ukko, J., Pekkola, S., Valtonen, J., Saunila, M. and Rantanen, H. (2011), "Productising expert services of performance management", International Journal of Business Excellence, Vol. 4 No. 2, pp. 125-141.

Valminen, K. and Toivonen, M. (2012), "Seeking efficiency through productisation: a case study of small KIBS participating in a productisation project", Service Industries Journal, Vol. 32 No. 2, pp. 273-289.

Valtakoski, A. and Järvi, K. (2016), "Productization of knowledge-intensive services: enabling knowledge sharing and cross-unit collaboration”, Journal of Service Management, Vol. 27 No. 3, pp. 360-390.

Voss, C., Tsikriktsis, N. and Frohlich, M. (2002), "Case research in operations management", International Journal of Operations and Production Management, Vol. 22 No. 2, pp. 195-219.

Wirtz, J. (2021), "Viewpoint: service products, development of service knowledge and our community's target audience", Journal of Services Marketing, Vol. 35 No. 3, pp. 265-270, doi: 10.1108/JSM-032020-0086.

Ye, L. (2019), “Chinese academic library research evaluation services”, Journal of Library Administration, Vol. 59 No. 1, pp. 97-128.

Yin, R.K. (2013), Case Study Research: Design and Methods, 5th ed., Sage, Thousand Oaks, California, CA.

Yuen, K.F. and Thai, V.V. (2017), "The influence of supply chain integration on operational performance: a comparison between product and service supply chains", The International Journal of Logistics Management, Vol. 28 No. 2, pp. 444-463.

\section{Corresponding author}

Janne Harkonen can be contacted at: janne.harkonen@oulu.fi

For instructions on how to order reprints of this article, please visit our website:

www.emeraldgrouppublishing.com/licensing/reprints.htm

Or contact us for further details: permissions@emeraldinsight.com 